\title{
The significance of resorcinol/resorcylate in the
} \section{structure of anti-cancer therapeutics targeting Hsp90: Synthesis and structure-activity relationship (SAR) studies}

\author{
Garba Suleiman ${ }^{1 *}$, Muktari Isa Shago ${ }^{2}$, Abba Mohammed $^{3}$, Mohammed Nuhu Alamai ${ }^{4}$ \\ ${ }^{1}$ Department of Chemistry, Faculty of Science, Yobe State University, Damaturu, Nigeria \\ ${ }^{2,3}$ Department of Biochemistry, Faculty of Science, Yobe State University, Damaturu, Nigeria \\ ${ }^{4}$ College of Health Science \& Technology, Nguru, Yobe State, Nigeria
}

\begin{abstract}
The number of people suffering from cancer has been increasing rapidly over the years, placing a huge burden on our societies. The development of heat shock protein (hsp) inhibitors, especially Hsp90 signifies an alternative method for cancer therapy. Thanks to the plenty of similar overlapping regions that exist between cancer and Hsp90, proteins associated with cancer have been able to regulate the expression of Hsp90 via heat shock fator-1 (HSF-1). Because of the relationship between Hsp90 with Cancer, Alzheimer and Parkinson's diseases we will put more emphasis on synthetic methodologies, structure-activity relationships and the significance of structures containing resorcinol moiety targeting those disorders.
\end{abstract}

Keywords: Cancer, Hsp90 inhibitors, resorcinol, resorcylate, molecular chaperone.

\section{INTRODUCTION}

$\mathrm{T}$ he development of heat shock protein 90 (Hsp90) inhibitors as anti-cancer therapeutic agents is one of the major areas of concern in medicinal chemistry (1).Cancer, a disease caused as a result of uncontrollable cell division, is the second most notable cause of death around the globe, which has, over the years, become one of the critical challenges for humanity in almost every part of the world. According to a recent report, cancer averagely causes over 500,000 deaths every year, with an estimated peak of around 13 million to be reached by 2030 . Thanks to the plenty of similar overlapping regions between cancer and Hsp90, proteins associated with cancer have been able to regulate the expression of Hsp90 via heat shock factor-1 (HSF-1).

Heat shock protein 90 is a highly conserved molecular chaperone abundant in the cytoplasm of normal eukaryotic cells used in maintaining protein homeostasis. It is an ATP dependent member of a multi-chaperone complex responsible for the conformational maturation, stabilization, folding, and activation of the client proteins directly related to cancer metastasis. Such client proteins are typically cancer-relevant targets like kinases, growth factors, signaling proteins, steroid receptors, transcription factors, and cell-cycle regulators. Several of these Hsp90 dependent client proteins responsible for protein homeostasis include but are not limited to, the following: Her2, Akt, Raf1, CDK6, telomerase, etc. They were reported to be involved in the malignant transformation and progression of cancer. Besides, they were identified to be directly related to all the ten hallmarks of cancer. Consequently, inhibition of Hsp90 can simultaneously regulate multiple targets by providing a combinatorial attack against proliferation and cancer cell survival.

Although Hsp90 inhibitors have displayed significant anticancer activities in several tumor cells currently in clinical trials, none of these drugs was able to show appreciable mono-therapeutic activity due to adverse effects, including low solubility and exposure. However, combination therapy of Hsp90 inhibitors with targeted anti-cancer drugs has shown synergistic effects by overcoming resistance. Because of the ability of the Hsp90 to interact with over 400 client proteins, many of which are directly associated with human diseases like cancer, and the fact that its inhibition degrades oncogenic client proteins due to oxidative stress, it is widely considered as a future therapeutic target for numerous death-causing disorders in humans. To illustrate, cancer, Alzheimer's, and Parkinson's diseases belong to this therapeutic target category $(2-8)$.

\section{HSP90 AND ITS STRUCTURE}

HSP90, as a kind of molecular chaperone, comprises of four different isoforms, each of which localized in distinct cellular locations: the stress-induced HSP90 $\alpha$ and the constitutively expressed HSP90 $\beta$ reside in the cytosol, Grp94 is localized to the endoplasmic reticulum, and Trap1 is found in the mitochondria $(2,9,10-13)$.Structurally, HSP90 exists as a homodimer with three structural domains: the N-terminal domain containing an ATP-binding site; the middle domain with client proteins binding sites and the C-terminal generally responsible for the dimerization (Figure 1)(10, 11).For many years, the N-terminal domain has been researched extensively as an attractive target for cancer therapy, nevertheless despite many efforts poured on these binders, none of them (the so- 
called "classical inhibitors") has yet passed all the clinical trials successfully due to the detrimental and chemoprotective effects leading to the induction of a heat shock response. Alternatively, C-terminal binders have been equally researched. For example, some derivatives of novobiocin and coumermycin antibiotics have been reported to bind weakly to the c-terminal ATP binding site, inhibiting Hsp90 function, and inducing degradation of client proteins without a heat shock response. That has given new assurances to medicinal chemists to develop new Hsp90 inhibitors for cancer therapies $(10,13)$.

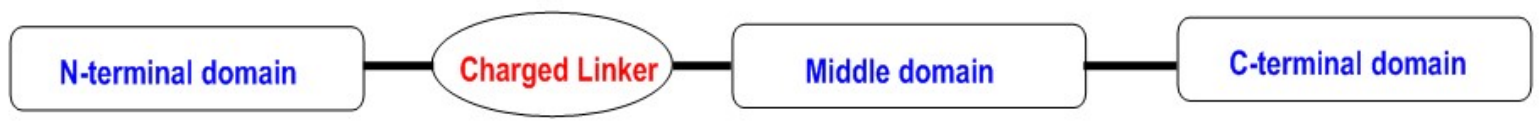

$\begin{array}{ll}\text { Functions } & \text { Functions } \\ \text {-ATPase } & \text {-Flexibility } \\ \text {-Co-chaperone binding } & \end{array}$

\section{Functions \\ -Client protein binding \\ -ATPase activation \\ -Co-chaperone binding}

\section{Functions \\ -Client protein binding -Co-chaperone binding -Dimerization}

Figure 1: Structure and Function of hsp90

Anti-cancer drug development has been heavily focused on improving existing drugs to act against a specific target with high potency and selectivity. Among the excess number of compounds screened for their Hsp90 inhibitory activity, derivatives possessing the resorcinol and/or resorcylate structural moieties have currently gathered a significant interest. Radicicol (Figure 2), the first naturally occurring derivative of resorcylic acid lactone, was first isolated in 1953 from plant-associated fungus or fungal metabolites, chaetomium chiversii. This compound initially displayed mild sedative and antibiotic activity, which was later discovered to show an exceptional inhibitory effect against Hsp90. Radicicol and geldanamycin (Figure 2) are the first generation Hsp90 inhibitors that bind to the N-terminal via ATP binding domain, structurally mimicking and inhibiting the hydrolysis of ATP, leading to the degradation of oncogenic client proteins (13).

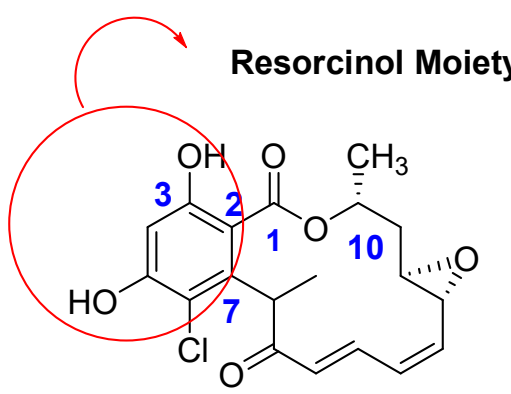

Figure 2: Natural products Hsp90 inhibitors: a) Radicicol

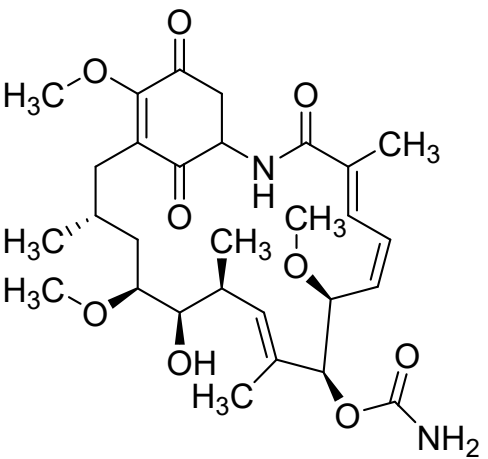

b) Geldanamycin structures
Although radicicol and derivatives have offered a piece of experimental evidence for Hsp90 inhibitors in cancer therapy, clinical investigations have revealed the induction of heat shock response in addition to other issues like low solubility and being unstable in the plasma. However, this important scaffold has exhibited strong Hsp90 inhibitory activity thanks to the resorcinol (Figure 2) moiety that binds toaspartateresidue via its 3 - hydroxyl group $(14,15)$.Unlike geldanamycin containing derivatives, those holding the resorcinol moiety varied greatly in their structure and are only roughly interrelated by their pharmacophore.
A recent update on achievements, challenges, and future directions concerning natural products hsp90 inhibitors and synthetic molecules, reaffirmed the increased importance of resorcinol pharmacophore in the activity of the newly developed Hsp90 N-terminal ATP inhibitors (Figure 3) (16, 17). The anti-proliferative activity of (a) Radicicol and (b) KF25706against MCF-7 and KNRK5.2 cell lines were represented by the $\mathrm{IC}_{50}$ values of $30 n M \& 39 n M$, respectively. On the other hand, the fluorescence polarization assay was employed in determining the $\mathrm{IC}_{50}$ values of compounds $\mathbf{f}-\mathbf{h}$. The $\mathrm{IC}_{50}$ values of $\mathbf{i}$ and $\mathbf{j}$ represent the anti-proliferative activity against the MDA-MB-231 cell line. 
<smiles>CC(=O)OC(=O)c1c(O)cc(O)c(Cl)c1C(C)C(=O)/C=C\C=C/[C@@H](C)O</smiles>

a: Radicicol, $\mathrm{IC}_{50}=30 \mathrm{nM}$<smiles>C=CC=CC(C)c1cc(C(=O)N2Cc3ccccc3C2)c(O)cc1O</smiles><smiles>c1ccccc1</smiles><smiles>C=CC1=C(c2ccc3c(c2)OCCO3)C=CC1=C(C)C</smiles>

f: $\mathrm{IC}_{50}=280 \mathrm{nM}$<smiles>C=C=C(C)c1cc(-c2onc(C(=O)NCC)c2-c2ccc(CN3CCOCC3)cc2)c(O)cc1O</smiles>

g: $\mathrm{IC}_{50}=\mathbf{2 5 n M}$

h: $\mathrm{IC}_{50}=\mathbf{2 1} \mathbf{n M}$<smiles>CCC(=O)/C=C\C=C/C(=O)C(C)c1c(Cl)c(O)cc(O)c1C(=O)OC(C)=O</smiles>

b: $\mathrm{KF} 25706, \mathrm{IC}_{50}=\mathbf{3 9 n} \mathbf{M}$<smiles>CCNc1nc(OCCOC)nc2c1CN(C(=O)c1cc(C(C)C)c(O)cc1O)CC2</smiles>

i: $I C_{50}=119 \mathrm{nM}$<smiles>O=C(NCc1ccccc1)[C@@H]1Cc2ccccc2CN1C(=O)c1cc(Cl)c(O)cc1O</smiles>

$\mathrm{j}: I C_{50}=980 \mathrm{nM}$

Figure 3: Hsp90 N-terminal ATP inhibitors containing the resorcinol scaffold

Due to the advantages of resorcinol based structures manifesting comparable potency against all four Hsp90 isoforms, multi-mechanism role against many oncogenic pathways (17), and wide-ranging potency against several diseases, there is increasingly a tremendous effort on the optimization of the existing structures. Onalespib, Luminespib \& Ganetespib are some of the biologically active resorcinol derivatives under clinical evaluation (Figure 4).<smiles>CC(C)c1cc(C(=O)N2Cc3ccc(CN4CCN(C)CC4)cc3C2)c(O)cc1O</smiles>

Onalespib<smiles>CCNC(=O)c1noc(-c2cc(C(C)C)c(O)cc2O)c1-c1ccc(CN2CCOCC2)cc1</smiles>

Luminespib<smiles>CC(C)c1cc(-c2nnc(O)n2-c2ccc3c(ccn3C)c2)c(O)cc1O</smiles>

\section{Ganetespib}

Figure 4: Some clinical resorcylate hsp90 inhibitors under clinical evaluation in oncology.

The 4- isopropyl resorcinol portion in the structures of Onalespib, Luminespib\&Ganetespib hsp90 inhibitors is a crucial structural fragment reported to have not only fit into the hydrophobic and hydrophilic regions of the protein but 
also served as a keynote binder related with the ATP binding domain of heat shock proteins(17).Because of the relationship between hsp90 with Cancer, Alzheimer, and Parkinson's diseases, we will feature a few drugs containing resorcinol moiety targeting those diseases. For example, entacapone is a selective, reversible inhibitor administered in combination with levodopa to treat patients with shaking palsy, also called Parkinson's disorder. (Figure 5). It is our belief; this minireview will be useful in the design, SAR, and the developments of powerful resorcinol-based drugs targeting various death-causing diseases beyond cancer.(18-22).<smiles>CCC(CC)C(=O)/C(C#N)=C/c1cc(O)c(O)c([N+](=O)[O-])c1</smiles>

Figure 5: Entacapone, a drug used in the treatment of Parkinson's disease.

\section{SYNTHETIC ROUTES AND SAR OF RESORCINOL CONTAINING HSP90 INHIBITORS}

Ojiha and co-workers (23) designed and developed a novel series of resorcinol bearing indoline derivatives as potent dual<smiles>CC1Cc2cc([N+](=O)[O-])ccc2N1</smiles>

14<smiles>CC(C)c1cc(C(=O)N2CCc3cc([N+](=O)[O-])ccc32)c(OCc2ccccc2)cc1OCc1ccccc1</smiles>

15
Hsp90/HDAC inhibitor as shown in scheme 1. The introduction of resorcinol pharmacophore, at $\mathrm{N}-\mathrm{H}$ of 5nitroindoline was achieved via amide coupling of the 5nitroindoline with 2,4-bis(benzyloxy)-5-isopropylbenzoic acid using oxalyl chloride as an auxiliary reagent in DCM at room temperature to yield the intermediate 15 , which underwent subsequent reduction with iron and ammonium chloride to generate the amine 16. Further treatment of 16 with alkoxy oxoalkanoic acids yield ester intermediates $17 a-g$ which were subjected to hydrolysis in the presence of $\mathrm{LiOH}$ to generate the carboxylic acids $17 h-n$. In the nextstep, the intermediates $17 h-n$ were coupled with $\mathrm{NH}_{2} \mathrm{OBn} . \mathrm{HCl}$ in the presence of $\mathrm{EDC} / \mathrm{HOBt}$ as the coupling reagent and DIEA as the base yielding amides $17 o-u$. Finally, the amides were debenzylated by employing $10 \% \mathrm{Pd} / \mathrm{C}$ in $\mathrm{MeOH}$ at $40-42 \mathrm{psi}$, affording the targeted resorcinol-bearing hydroxamic acid derivatives $18 a-$ $e$. All the compounds screened displayed more potent HSP90 inhibition than BIIB021-an orally available small-molecule HSP90 inhibitor $\left(I C_{50}=65.7 n M\right)$ used as a standard. Among all the tested derivatives $18 \mathrm{a}-\mathrm{g}$, compounds $18 \mathrm{~d}$ and $18 \mathrm{e}$ were found to be the most potent $\mathrm{HSP} 90$ inhibitors with $\mathrm{IC}_{50}$ values of 40.2 and $46.3 n M$, respectively. The SAR revealed that the presence of the isopropyl resorcinol moiety influenced the ability of the compounds 18a-e to inhibit Hsp90 protein. However, the linker length had very little or no influence on the Hsp90 inhibitory effects of the molecules.<smiles>CC(C)c1cc(C(=O)N2CCc3cc(NC(=O)[Ga]C(=O)NO)ccc32)c(O)cc1O</smiles>

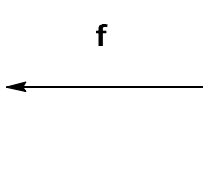

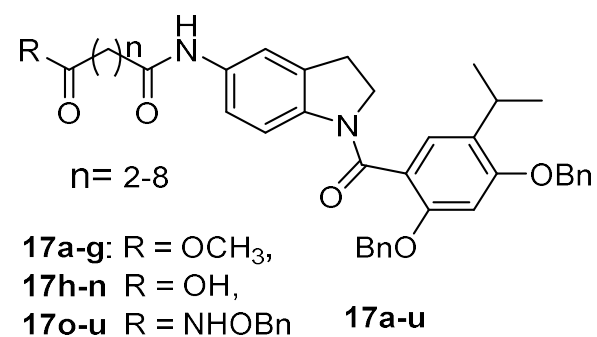

The presence of resorcinol significantly increases the activity

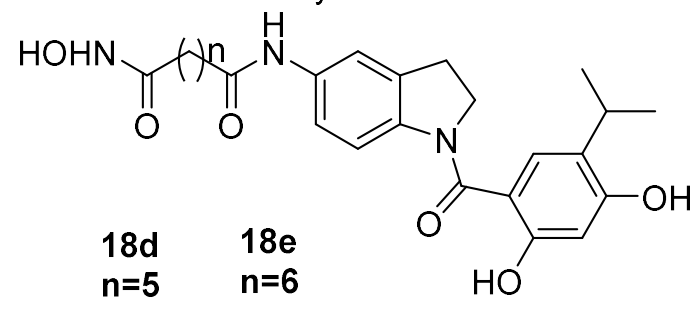




\section{Reagents and conditions:}

a) i) 2,4-bis(benzyloxy)-5-isopropylbenzoic acid,oxalyl chloride, $\mathrm{CH}_{2} \mathrm{Cl}_{2}$, rt; ii) EDC, HOBt, DIPEA, DMF, rt; b) Fe, $\mathrm{NH}_{4} \mathrm{Cl}, \mathrm{EtOH} / \mathrm{H}_{2} \mathrm{O}$, reflux; c) alkoxy oxoalkanoic acids, EDC, HOBt, DIPEA, DMF, rt; d) LiOH (1M, aq), dioxane, $40{ }^{\circ} \mathrm{C}$; e) $\mathrm{NH}_{2} \mathrm{OBn} . \mathrm{HCl}$, EDC, HOBt, DIPEA, DMF, rt; f) $\mathrm{Pd} / \mathrm{C}, \mathrm{H}_{2}$, $\mathrm{MeOH}, \mathrm{rt}$.<smiles>CC(=O)c1ccc(O)cc1O</smiles>

19<smiles>COc1ccc(C(C)=O)c(OC)c1</smiles>

20
Scheme 1: Synthetic routes for resorcinol-bearing indoline analogs as potent dual Hsp90/HDAC inhibitors

In 2014, Seo and Jeong developed a new series of butein analogs via a multi-step reaction routeand screened their antiproliferative activity against Gefitinib-resistant NSCLC (H1975) (24). The synthetic route was outlined in Scheme 2.<smiles>[R4]c1cc(/C=C/C(=O)c2ccc(O)cc2O)c([R])c([R2])c1[R3]</smiles><smiles>[R14]c1cc(C=O)c([R1])c([R1])c1[R1]</smiles><smiles>[R4]c1cc(/C=C/C(=O)c2ccc(O[Al])cc2O)c([R1])c([R1])c1[R1]</smiles>

Not only resorcinol, but also presence of 3,4,5-trimethoxy substituents highly influenced the antiproliferative activity<smiles>COc1cc(/C=C/C(=O)c2ccc(O)cc2O)cc(OC)c1OC</smiles>

Reagents and Conditions:

(a) Allyl bromide, $\mathrm{K}_{2} \mathrm{CO}_{3}$, DMF (b) aldehydes, allyl protected ketone 20 , $\mathrm{KOH}, \mathrm{EtOH}, 50^{\circ} \mathrm{C}$ (c)Claisen-Schmidt aldol condensation product $23, \mathrm{PdCl}_{2}$ $\left(\mathrm{PPh}_{3}\right)_{2}, \mathrm{NH}_{4} \mathrm{HCO}_{2}$, THF, $\mu \mathrm{w}, 120^{\circ} \mathrm{C}$

Scheme 2: Butein synthesis via Claisen-Schmidt aldol condensation of 20 with $21 \mathrm{a}-\mathrm{k}$ in basic medium

The synthesis of butein derivatives started with the protection of dihydroxyacetophenone 19 with allyl bromide in the presence of $\mathrm{K}_{2} \mathrm{CO}_{3}$ in DMF to furnish the allyl-protected ketone 20 inexcellent yield. Compound 20 was then subjected to Claisen-Schmidt aldol condensation with aldehydes $21 \mathrm{a}-\mathrm{k}$ in the presence of $\mathrm{KOH}$ in EtOH to successfully furnish compound $22 \mathrm{a}-\mathrm{k}$ which subsequently underwent mild and selective palladium-catalyzed deallylation with the aid of $\mathrm{PdCl}_{2}\left(\mathrm{PPh}_{3}\right)_{2}$ and ammonium formate in THF to finally yield the targeted butein analogues 23a-k. Anti-proliferativeactivity studies of the analogsagainstH1975 cell line throughHsp90inhibition were undertaken by firstincubating<smiles>COc1cc(/C=C/C(=O)c2ccc(O)cc2O)c(Br)c(OC)c1OC</smiles>

H1975 cells with $30 \mu \mathrm{M}$ of butein analogs 23a-k for $72 \mathrm{~h}$. Later on, the cell viability was measured using MTS colorimetric assay, and percent inhibition of H1975 cell proliferation by each analog 23a-k relative to DMSO control was determined. Among all the analogs tested by the assay, compounds $23 \mathrm{f}$ and $23 \mathrm{~h}$ effectively reduced the growth of H1975 cells and demonstrated 69 and $61 \%$ inhibition, respectively. Specifically, compound $23 \mathrm{~h}$ inhibited the proliferation of H1975 cells, down-regulated the expression of Hsp90 client proteins, Met, Akt, Her2, Cdk4, and EGFR, and up-regulated the expression of Hsp70 as the most potent of all scaffolds.

SAR studies revealed that the presence of resorcinol moiety, as well as the halogen together with the methoxy groups, played a significant role in the biological activities recorded for all the tested scaffolds as all of them were found to illustrate a moderate growth inhibitory activity against the Gefitinib resistant NSCLC cells (H1975) $(9,25)$. 
<smiles>CC(=O)c1ccc(O)cc1O</smiles>

19<smiles>CC(C)C</smiles>

24<smiles>O=C(/C=C/c1ccc(O)c(O)c1)c1ccc(O)cc1O</smiles>

25

Reagents and Conditions: (a) $\mathrm{SOCl}_{2}$, EtOH, RT, 1-2 h

Scheme 3: Synthetic route to Butein Derivatives

Recently, Hou and co-workers (26)reported an improved method for synthesizing butein via aldol condensation reaction employing $\mathrm{SOCl}_{2} / \mathrm{EtOH}$ for the first time as a catalyst. Unlike butein analogs reported by Seo and his group (24),this analog was synthesized and analyzed as xanthine oxidase (XO) inhibitor. The synthetic approach was outlined in Scheme 3. The synthesis involved aldol condensation reaction between 2, 4-dihydroxyacetophenone $\mathbf{2 3}$ and 3, 4dihydroxybenzaldehyde $\mathbf{2 4}$ catalyzed by thionyl chloride in ethyl alcohol at room temperature for $1 \mathrm{~h}$ to yield targeted butein analogue in good yield. Its XO inhibitory activity was determined via the formation of uric acid by employing xanthine as the substrate in the initial stage. Then, it was further examined using the following parameters including inhibition kinetic, fluorescence titration, synchronous fluorescence spectroscopy, and molecular docking studies. The molecular docking studies revealed butein as an effective XO inhibitor. Moreover, the in vitro studies revealed that butein could drastically decrease uric acid concentration with $\mathrm{IC}_{50}$ value of $2.93 \times \mathbf{1 0}^{-6} \mathbf{M}$. Overall, the results implied that butein was an effective XO inhibitor compared to a known $\mathrm{XO}$ inhibitor, allopurinol, due to the presence of carbonyl group and four hydroxyl groups on the two phenyl rings. In other words, the presence of two resorcinol pharmacophores connected by $\alpha, \beta$ - unsaturated carbonyl group resulted in the significant activity displayed by the newly prepared butein.

In 2018, Khandelwal and colleagues (15) reported a new and diverse series of Hsp90 $\beta$ N-terminal isoform-selective inhibitors. They screened for their in vitro anti-proliferative activity against NCI H23 (non-small cell lung cancer), UC3 (bladder cancer), HT-29 (colon adenocarcinoma) cells, and non-cancerous HEK 293 (human embryonic kidney) cells. Compound $\mathbf{2 5}$ was treated withhexamethylenetetramine (hexamine) in trifluoroacetic acid (TFA) at $100^{\circ} \mathrm{C}$ for $14 \mathrm{~h}$ after which it was cooled to room temperature, solvent removed. The residue was further treated with $3 \mathrm{M}$ hydrochloric acid at $60^{\circ} \mathrm{C}$ for $3 \mathrm{~h}$. The target compound 26 was isolated following a series of extraction protocols and further purified via column chromatography. In the next step, compound 26 was treated with $\mathrm{NaBH}_{4}$ in a $\mathrm{THF} / \mathrm{MeOH}$ solvent mixture at $0^{\circ} \mathrm{C}$ for $1 \mathrm{~h}$. Subsequent addition of $1 \mathrm{M}$ hydrochloric acid followed by extraction yielded the targeted compound $\mathbf{2 7}$ in good yield. A solution of $\mathbf{2 6}$ in acetonitrile at ambient temperature was treated with triflic acid and sodium azide. The resulting mixture was stirred for $5 \mathrm{~min}$ and concentrated. The residue was treated with water, extracted with ethyl acetate, dried and concentrated to afford a crude mixture. The crude product was further purified via preparatory TLC $\left(\mathrm{SiO}_{2}\right)$ to afford compounds 28 and 29 in $37.8 \%$ and $27.1 \%$ yield, respectively.<smiles>CC(C)c1cc(C(=O)N2Cc3ccccc3C2)c(O)cc1O</smiles>

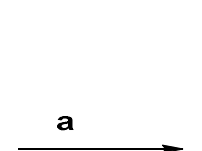

25<smiles>CC(C)c1cc(C(=O)N2Cc3ccccc3C2)c(O)c(C=O)c1O</smiles>

26<smiles>CC(C)c1cc(C(=O)N2Cc3ccccc3C2)c2oncc2c1O</smiles><smiles>CC(C)c1cc(C(=O)N2Cc3ccccc3C2)c2oncc2c1O</smiles><smiles>CC(C)c1cc(C(=O)N2Cc3ccccc3C2)c(O)c(CO)c1O</smiles>

27 


\section{Reagents and Conditions:}

(a) (i) hexamine, $\mathrm{TFA}, 100^{\circ} \mathrm{C}, 14 \mathrm{~h}$ (ii) $3 \mathrm{M} \mathrm{HCl}, 60^{\circ} \mathrm{C}, 3 \mathrm{~h}$ (b) aldehyde 26 , $\mathrm{NaBH}_{4}, \mathrm{THF} / \mathrm{MeOH}, 0^{\circ} \mathrm{C}, 1 \mathrm{~h}$ (c) TFA, $\mathrm{NaN}_{3}, \mathrm{CAN}, \mathrm{rt}$.

Scheme 4: Synthetic route to resorcinol containing isoindoline analog 27, 28 \& 29 via two-step

\section{CONCLUSION}

Heat-shock proteins, particularly Hsp90, are prominent for their extraordinary degree of sequence preservation amongst species. As contained in this mini-review, the examples illustrated the potential of structure-activity relationship values in disrupting many fatal disorders beyond cell proliferation. The research mostly focused on the structural revision of a few synthetically obtained resorcinol/resorcylate containing molecules. It is evident that small changes around the functionality of resorcinol structure could have a significant impact on the overall activities of the analogs.

\section{REFERENCES}

[1] Lee JH, Shin SC, Seo SH, Seo YH, Jeong N, Kim CW, et al. Synthesis and in vitro anti-proliferative activity of C5-benzyl substituted 2-amino-pyrrolo[2,3-d]pyrimidines as potent Hsp90 inhibitors. Bioorg Med Chem Lett. 2017;27(2):237-41.

[2] Wang H, Tan MS, Lu RC, Yu JT, Tan L. Heat shock proteins at the crossroads between cancer and Alzheimer's disease. Biomed Res Int. 2014;2014:239164.

[3] Calderon PB, Beck R, Glorieux C. Targeting hsp90 family members: A strategy to improve cancer cell death. BiochemPharmacol. 2019;164:177-187.

[4] Gupta SD, Bommaka MK, Banerjee A. Inhibiting protein-protein interactions of Hsp90 as a novel approach for targeting cancer. Eur J Med Chem. 2019;178:48-63.

[5] Li N, Xu M, Wang B, Shi Z, Zhao Z, Tang Y, Wang X, Sun J, Chen L. Discovery of Novel Celastrol Derivatives as Hsp90Cdc37 Interaction Disruptors with Antitumor Activity. J Med Chem. 2019;62(23):10798-10815.

[6] Millson SH, Prodromou C, Piper PW. A simple yeast-based system for analyzing inhibitor resistance in the human cancer drug targets Hsp90alpha/beta. BiochemPharmacol. 2010;79(11):1581-8.

[7] Ernst JT, Liu M, Zuccola H, Neubert T, Beaumont K, Turnbull A, Kallel A, Vought B, Stamos D. Correlation between chemotypedependent binding conformations of $\mathrm{HSP} 90 \alpha / \beta$ and isoform selectivity-Implications for the structure-based design of HSP90 $\alpha / \beta$ selective inhibitors for treating neurodegenerative diseases. Bioorg Med Chem Lett. 2014;24(1):204-8.

[8] Garg G, Zhao H, Blagg BS. Design, synthesis and biological evaluation of alkylamino biphenylamides as Hsp90 C-terminal inhibitors. Bioorg Med Chem. 2017;25(2):451-457.

[9] Khandelwal A, Crowley VM, Blagg BSJ. Resorcinol-Based Grp94-Selective Inhibitors. ACS Med Chem Lett. 2017;8(10):1013-8

[10] Terracciano S, Russo A, Chini MG, Vaccaro MC, Potenza M, Vassallo A, et al. Discovery of new molecular entities able to strongly interfere with Hsp90 C-terminal domain. Sci Rep. 2018;8(1):1709.
[11] Buckton LK, Wahyudi H, McAlpine SR. The first report of direct inhibitors that target the C-terminal MEEVD region on heat shock protein 90. Chem Commun (Camb). 2016;52(3):501-4.

[12] Goode KM, Petrov DP, Vickman RE, Crist SA, Pascuzzi PE, Ratliff TL, et al. Targeting the Hsp90 C-terminal domain to induce allosteric inhibition and selective client downregulation. Biochim Biophys Acta Gen Subj. 2017;1861(8):1992-2006.

[13] Jana N, Nanda S. Resorcylic acid lactones (RALs) and their structural congeners: recent advances in their biosynthesis, chemical synthesis and biology. New Journal of Chemistry. 2018;42(22):17803-73.

[14] Tutar L, Coskun KA, Tutar Y. New Generation Cancer Drug Studies: Hsp90 Inhibitors. Single Cell Biology. 2016;05(04).

[15] Khandelwal A, Kent CN, Balch M, Peng S, Mishra SJ, Deng J, et al. Structure-guided design of an Hsp90beta N-terminal isoformselective inhibitor. Nat Commun. 2018;9(1):425.

[16] Huang DS, LeBlanc EV, Shekhar-Guturja T, Robbins N, Krysan DJ, Pizarro J, et al. Design and Synthesis of Fungal-Selective Resorcylate Aminopyrazole Hsp90 Inhibitors. J Med Chem. 2020;63(5):2139-80.

[17] Li L, Wang L, You QD, Xu XL. Heat Shock Protein 90 Inhibitors: An Update on Achievements, Challenges, and Future Directions. J Med Chem. 2020;63(5):1798-822.

[18] Crowley VM, Khandelwal A, Mishra S, Stothert AR, Huard DJ, Zhao J, Muth A, Duerfeldt AS, Kizziah JL, Lieberman RL, Dickey CA, Blagg BS. Development of Glucose Regulated Protein 94 Selective Inhibitors Based on the BnIm and Radamide Scaffold. J Med Chem. 2016;59(7):3471-88.

[19] Ernst JT, Liu M, Zuccola H, Neubert T, Beaumont K, Turnbull A, Kallel A, Vought B, Stamos D. Correlation between chemotypedependent binding conformations of HSP $90 \alpha / \beta$ and isoform selectivity-Implications for the structure-based design of HSP90 $\alpha / \beta$ selective inhibitors for treating neurodegenerative diseases. Bioorg Med Chem Lett. 2014;24(1):204-8.

[20] Meng T, Zhang D, Xie Z, Yu T, Wu S, Wyder L, Regenass U, Hilpert K, Huang M, Geng M, Shen J. Correction to "Discovery and Optimization of 4,5-Diarylisoxazoles as Potent Dual Inhibitors of Pyruvate Dehydrogenase Kinase and Heat Shock Protein 90". J Med Chem. 2019;62(23):10926

[21] Bickel D, Gohlke H. C-terminal modulators of heat shock protein of $90 \mathrm{kDa}$ (HSP90): State of development and modes of action. Bioorg Med Chem. 2019;27(21):115080.

[22] Jung S, Yoon NG, Yang S, Kim D, Lee WS, Hong KB, Lee C, Kang BH, Lee JH, Kang S. Discovery of 2-((4-resorcinolyl)-5aryl-1,2,3-triazol-1-yl)acetates as potent Hsp90 inhibitors with selectivity over TRAP1. Bioorg Med Chem Lett. 2020;30(2):126809.

[23] Ojha R, Huang HL, HuangFu WC, Wu YW, Nepali K, Lai MJ, et al. 1-Aroylindoline-hydroxamic acids as anti-cancer agents, inhibitors of HSP90 and HDAC. Eur J Med Chem. 2018;150:66777.

[24] Seo YH, Jeong JH. Synthesis of Butein Analogues and their Antiproliferative Activity Against Gefitinib-resistant Non-small Cell Lung Cancer (NSCLC) through Hsp90 Inhibition. Bulletin of the Korean Chemical Society. 2014;35(5):1294-8.

[25] Trendowski M. PU-H71: An improvement on nature's solutions to oncogenic Hsp90 addiction. Pharmacol Res. 2015;99:202-16.

[26] Hou YX, Sun SW, Liu Y, Li Y, Liu XH, Wang W, et al. An Improved Method for the Synthesis of Butein Using SOCl2/EtOH as Catalyst and Deciphering Its Inhibition Mechanism on Xanthine Oxidase. Molecules. 2019;24(10) 